\title{
LA EVOLUCIÓN DE LAS COMPETENCIAS COMPARTIDAS BASES-DESARROLLO
}

JOSÉ ANTONIO MONTILLA MARTOS 
SUMARIO

1. LAS COMPETENCIAS COMPARTIDAS BASES-DESARROLLO EN LA CONSTITUCIÓN; 2. LA CONCEPCIÓN MATERIAL DE LO BÁSICO COMO GARANTÍA DEL DESARROLLO NORMATIVO AUTONÓMICO EN LOS ORÍGENES DEL ESTADO AUTONÓMICO; 3. LA FORMALIZACIÓN DE LO BÁSICO Y SUS LÍMITES; 3.1. Las fuentes en las que se contienen las bases; 3.2. El alcance o extensión de las bases; 4. LA DESFORMALIZACIÓN E ILIMITADA EXPANSIÓN DE LO BÁSICO A PARTIR DE LA STC 31/2010; 5. LA IMPOSICIÓN DE LAS BASES SOBRE EL ESTATUTO DE AUTONOMÍA A PARTIR DE LA STC 31/2010; 6. LA APLICACIÓN DE LA CLÁUSULA DE PREVALENCIA PARA LA INAPLICACIÓN DE NORMAS AUTONÓMICAS CONTRARIAS A BASES SOBREVENIDAS; 7. CONCLUSIÓN: LA NECESIDAD DE MODIFICAR LA FORMA DE DETERMINAR LO BÁSICO. 


\title{
LA EVOLUCIÓN DE LAS COMPETENCIAS COMPARTIDAS BASES-DESARROLLO
}

\author{
JOSÉ ANTONIO MONTILLA MARTOS ${ }^{1}$ \\ Universidad de Granada
}

\section{LAS COMPETENCIAS COMPARTIDAS BASES-DESARROLLO EN LA CONSTITUCIÓN}

El reparto de las competencias compartidas entre el Estado y las Comunidades Autónomas es una de las cuestiones más discutidas y peor resueltas en la organización territorial de España. En todos los modelos descentralizados suelen generarse conflictos en el reparto competencial. Sin embargo, en España se agudiza esta cuestión por la conocida remisión a los Estatutos de Autonomía del reparto. Como es sabido, la Constitución establece un listado de materias de competencia exclusiva del Estado (art. 149.1 CE) a partir del cual las Comunidades podrán incorporar a sus Estatutos la competencia sobre lo que no esté reservado al Estado en la Constitución (art. 149.1.3 CE en relación al art. 147.2 d) CE). Sin embargo, esta singular forma de reparto se ha visto dificultada en la práctica por diversos motivos. En primer lugar, muchas de las materias enumeradas en el art. 149.1 CE no son de competencia exclusiva del Estado, pese a la dicción literal, sino compartida a través de dos procedimientos: en unos casos, el Estado es competente para establecer la legislación mientras que la ejecución puede ser asumida por las Comunidades Autónomas (arts. 149.1.6, 7, 8, 9, 12 16, 17, 22, 28 CE); en otros, la Constitución reserva al Estado la competencia para establecer las bases (condiciones básicas, legislación básica, normas básicas) pudiendo asumir la Comunidad Autónoma el desarrollo normativo y la ejecución de esas bases (arts. 149.1.1, 11, 13, 16, 17, 18, $23,25,27,30 \mathrm{CE}$ ). Pero, en segundo lugar, seguramente lo más relevante es que la competencia del Estado para establecer las bases no se refiere en algunos casos a una materia concreta sino que tiene un alcance horizontal pues se trata de estable-

${ }^{1}$ Catedrático de Derecho Constitucional. Universidad de Granada. Departamento de Derecho Constitucional. Facultad de Derecho. Plaza de la Universidad, 1. 18071 Granada. Email: montilla@ugr.es 
cer las bases sobre la «ordenación general de la actividad económica» (art. 149.1.13) o las «condiciones básicas» para garantizar la igualdad de todos los españoles en el ejercicio de los derechos o en el cumplimiento de los deberes constitucionales. La consecuencia es la inexistencia de competencias exclusivas de las Comunidades Autónomas pues en todas las materias que hubiera asumido en su Estatuto de Autonomía podrá incidir esa competencia transversal u horizontal del Estado para establecer las bases.

Se puede entender, por tanto, la importancia de este reparto competencial bases-desarrollo en la configuración del modelo de organización territorial. En este sentido, el objeto de estas páginas es explicar la evolución que ha tenido esa relación en la doctrina del Tribunal Constitucional que, como es sabido, se ha convertido en el primordial punto de referencia para el reparto competencial ${ }^{2}$.

Con este objeto, analizamos las razones por las que se parte de una concepción material de lo básico y nos detenemos en los intentos de formalización apuntados en la doctrina del Tribunal Constitucional para, posteriormente, reconocer expresamente la desformalización en la STC 31/2010. Las consecuencias de esta sentencia para las competencias compartidas han sido tan trascendentes que, en la práctica, han quedado absolutamente desfiguradas. Nos referimos, para mostrar esto, a dos fenómenos que derivan directamente de esa sentencia. En primer lugar, el Estado puede agotar la regulación de una materia con un título competencial básico de carácter horizontal, sin que la Comunidad pueda efectuar desarrollo normativo alguno pese a declarar el Estatuto su competencia exclusiva sobre esa materia (STC 93/2015); en segundo lugar, la normativa básica sobrevenida aprobada por el legislador estatal se impone sobre la disposición estatutaria que fue acordada entre las Cortes Generales y el Parlamento autonómico (STC 168/2016). Mencionamos, finalmente, el uso de la cláusula de prevalencia para inaplicar por los operadores jurídicos una norma autonómica que contradice a una norma básica sobrevenida (SSTC 102/2016, 204/2016). Este fenómeno no se vincula expresamente a la STC $31 / 2010$, e incluso puede resultar funcional desde la perspectiva de la relación entre ordenamientos, pero puede también incardinarse en la tendencia devaluadora del espacio competencial autonómico.

Ante esta desfiguración de las competencias compartidas bases-desarrollo, concluimos reiterando nuestra propuesta de cambiar la forma de configurar lo básico para garantizar la participación autonómica en su determinación. Sólo con esa participación puede aceptarse esa inmisión en el espacio competencial autonómico y, en definitiva, puede seguir manejándose la categoría competencial de las bases sin que conlleve en la práctica un proceso de recentralización competencial. En este contexto, la reconfiguración de las bases del Estado que proponemos se sustenta en tres pilares: las bases deben incluirse en una ley que garantice su estabilidad y certeza; han de

${ }^{2}$ He expuesto, en sentido crítico, esa función de delimitación competencial asumida por el Tribunal Constitucional en J.A. Montilla Martos, 2013, pp. 527-543. 
permitir a las regiones el desarrollo de políticas propias y deben establecerse con la participación de las regiones a través de un Consejo territorial que debería sustituir al actual Senado ${ }^{3}$.

\section{LA CONCEPCIÓN MATERIAL DE LO BÁSICO COMO GARANTÍA PARA EL DESARROLLO NORMATIVO AUTONÓMICO EN LOS ORÍGENES DEL ESTADO AUTONÓMICO}

Tras la entrada en vigor de la Constitución y la aprobación de los Estatutos de Autonomía (1979-1983) la articulación normativa bases-desarrollo en las competencias compartidas se hace a partir de una concepción puramente material, no formal, de lo básico. Sin embargo, esa concepción material ha perdido su justificación histórica. Resulta conocido que el Tribunal Constitucional, en su STC 32/1981, consagró ese concepto material en dos planos. En primer lugar, decía, era innecesaria la declaración formal de lo básico por el legislador estatal en cada una de las materias por cuanto «esos principios o criterios básicos, estén o no formulados como tales, son los que racionalmente se deducen de la legislación vigente» (FJ 6). En segundo lugar, la concepción de lo básico era material por la provisionalidad de una hipotética delimitación por el legislador estatal pues, aunque se haya establecido previamente lo que debe entenderse por básico, «será el Tribunal el competente para decirlo, en su calidad de intérprete supremo de la Constitución» (FJ 5). Por tanto, aunque la definición política de lo básico corresponde al legislador estatal, esa libertad configuradora se encuentra limitada en dos sentidos: ante su inacción, esto es, si no formula lo que es básico, el legislador autonómico puede actuar, respetando lo que considere criterios básicos aun no formulados de forma expresa, y, además, esa definición primera puede ser cuestionada ante el Tribunal Constitucional, a quien corresponde en último término su determinación. No era necesario, por tanto, que el Estado estableciera lo básico en cada una de las materias de forma expresa. El legislador autonómico podía ejercer su facultad competencial de desarrollo normativo a partir de una presunción de lo básico que, en todo caso, podía ser cuestionada ante el Tribunal Constitucional.

\footnotetext{
${ }^{3}$ Desde hace años vengo advirtiendo en los distintos trabajos recogidos en la bibliografía final de los riesgos de la forma de entender lo básico aceptada por el Tribunal Constitucional. En ese sentido, he propuesto tanto la formalización de lo básico como la participación de las Comunidades en su determinación. Por ello, las ideas que se exponen aquí han sido recogidas en trabajos anteriores. Incorporo ahora, no obstante, dos novedades jurisprudenciales. Por un lado, la confirmación en la práctica de que una norma básica puede imponerse sobre lo establecido en el Estatuto de Autonomía, con la devaluación de esa fuente que ello conlleva (STC 168/2016); por otro lado, la posibilidad de inaplicar directamente una norma autonómica que contradiga una norma básica posterior en virtud de la cláusula de prevalencia del artículo 149.1.3 CE (STC 102/2016).
} 
El motivo de esta concepción material era claro. Se trataba de garantizar a las Comunidades recién constituidas el ejercicio de las competencias reconocidas en sus respectivos Estatutos de Autonomía ante una hipotética inacción del legislador básico estatal. Por ello, para que las CCAA pudieran hacer el desarrollo normativo de las bases no era precisa la "precedencia (cronológica y no sólo jurídica) entre la ordenación estatal y la que en su desarrollo puedan disponer las CCAA» (J. Jiménez Campo, 1989, 53). Como señaló la STC 32/1981/6, la declaración formal de lo básico en cada una de las materias resultaba innecesaria por cuanto «esos principios o criterios básicos, estén o no formulados como tales, son los que racionalmente se deducen de la legislación vigente». Por tanto, el legislador autonómico podía actuar normativamente respetando lo que considere criterios básicos aún no formulados de forma expresa. Esa definición primera podía ser cuestionada ante el Tribunal Constitucional, a quien corresponde en último término determinar qué es lo básico.

Es importante reiterar que la habilitación a las CCAA para que dedujeran lo básico de la legislación vigente, sin necesidad de una previa declaración formal por parte del Estado, era una garantía de la posición de las CCAA ante una hipotética pasividad del Estado en los momentos posteriores a la entrada en vigor de la Constitución y la aprobación de los Estatutos. Se hacía posible el ejercicio de las competencias autonómicas aún ante la ausencia de normas posconstitucionales básicas que sirvieran de marco (STC 111/1986/4). Sin haberse establecido formalmente una legislación básica estatal, las CCAA podían legislar sobre las materias de su competencia respetando las bases estatales deducibles de normas preconstitucionales no contrarias a las mismas (STC 32/1981) o, en su caso, utilizando como parámetro único los límites constitucionales. Esa concepción material se justificaba en la voluntad de evitar que el ejercicio de las competencias autonómicas se viera dificultado por la inacción del Estado, como había ocurrido en Italia (S. Muñoz Machado, 1981, 100 ss.). De esta forma, se lograba la máxima efectividad de la Constitución y los Estatutos y, en definitiva, la garantía de la normatividad de la Constitución (J. Jiménez Campo, 1989, 53-54).

Otra consecuencia de esta concepción material era, lógicamente, que las bases no debían ser establecidas por el Estado en una ley específica con esa definición y carácter sino que al poder deducirse de la legislación vigente en relación a cada una de las materias podía ser también un Decreto o incluso una orden ministerial, esto es, en aras del inmediato ejercicio de las competencias autonómicas se soslayaba el carácter formal de las bases.

Incluso, es cierto que, más allá de la garantía de la posición de las CCAA frente a una hipotética inacción del Estado, el distinto quantum competencial de las CCAA dificultaba una declaración formal de las bases por parte del Estado, aplicable con el mismo alcance en todo el territorio. Por ello, la concepción material pretendía asegurar tanto la inmediata efectividad de las competencias autonómicas como la unidad del ordenamiento (J. Jiménez Campo, 1989, 49). 
Son presupuestos que a estas alturas de desarrollo autonómico deben considerarse superados. Cuarenta años después de la aprobación de la Constitución, resulta improbable la pervivencia de ámbitos materiales en los que el desarrollo normativo autonómico pueda producirse sin una previa normativa estatal posconstitucional y posestatutaria en la que se haya podido delimitar lo básico pero, sobre todo, resulta injustificable que el legislador estatal no haya ejercido su competencia para concretar lo básico en las materias respecto a las cuáles la Constitución así lo prevé. Por otro lado, tras la ampliación de competencias para las CCAA del art. 143 CE, prevista en los Acuerdos Autonómicos de 1992, su formalización jurídica a través de la LO 9/1992, las reformas estatutarias contenidas en las LLOO 1 a 11 de 1994 y las reformas estatutarias posteriores, aprobadas en el periodo 1996-1999, puede apuntarse que se ha producido una efectiva equiparación competencial entre las CCAA, sin perjuicio de algunas diferencias por la no culminación de determinados traspasos o el propio ejercicio del principio dispositivo. En consecuencia, la concepción primera de la relación entre las bases estatales y el desarrollo autonómico ha perdido el sentido que tuvo en sus orígenes.

Debe recordarse, en fin, que esta concepción material de lo básico ha tenido otra consecuencia importante cual es impedir un «verdadero debate político y democrático acerca de lo que merezca ser considerado como básico respecto a una materia» (F. Caamaño, 2000, 103). Ha sido el legislador autonómico o, en su caso, el legislador estatal quien ha decidido lo básico en cada materia de una forma unilateral, con el control delimitador del Tribunal Constitucional ante los habituales conflictos. No se ha producido, por ende, el imprescindible debate político entre quien debe garantizar la regulación común y a quien le corresponde el desarrollo normativo en cada territorio.

\section{LA FORMALIZACIÓN DE LO BÁSICO Y SUS LÍMITES.}

En consecuencia, la configuración material de las bases garantizó en los inicios del Estado autonómico el ejercicio de las competencias compartidas y, en general, el tránsito de un Estado unitario a un Estado descentralizado. Sin embargo, paulatinamente se iban modificando las condiciones objetivas en las que se gestó. Ha indicado el propio Tribunal que «una vez superada la etapa inicial del sistema de distribución de competencias, el concepto material de norma básica, sin perder su sentido y relevancia, se debe integrar con el reseñado componente formal que ha de adquirir una mayor trascendencia como garantía de certidumbre jurídica en la articulación de las competencias estatales y autonómicas» (STC 196/1997/5). Como se decía desde la primera jurisprudencia, era necesario formalizar lo básico como un elemento determinante de la distribución competencial pues lo contrario supondría mantener una «ambigüedad permanente» en cuanto el Estado podría «oponer sorpresivamente a las CCAA como norma básica cualquier precepto legal o reglamentario al margen de su rango o estructura» (STC 1/1982/1). 


\subsection{Las fuentes en las que se contiene las bases.}

Así lo parecía entender el Tribunal Constitucional de forma expresa desde la STC 69/1988, que se nos presenta como un punto de inflexión para exigir con más rigor la determinación formal de las bases del Estado en una ley, una vez superada la etapa de adaptación (E. Alvarez Conde, 2004, 32). Indicaba esa sentencia que los elementos formales en la determinación de las bases están dirigidos a garantizar una definición clara y precisa de los marcos delimitadores de las competencias autonómicas. Se pretende evitar, en definitiva, la incertidumbre jurídica (STC 69/1988/6). En ese sentido, la STC 69/1988 introdujo diversas garantías formales en el proceso de producción normativa de las bases del Estado. Por un lado, sólo a través de la ley se alcanzará, con las garantías inherentes al procedimiento legislativo, una determinación cierta y estable de los ámbitos respectivos de las competencias básicas estatales y las de desarrollo normativo autonómico; por otro, la ley debe declarar expresamente el alcance de las bases o, en su defecto, venir dotada de una estructura que permita inferir, directa o indirectamente, pero sin especial dificultad, su vocación o pretensión de ser bases. En consecuencia, aunque la Constitución no impone el uso de la ley, los rasgos estructurales propios de esta fuente (generalidad, estabilidad y certeza) la convierten en el vehículo adecuado para una definición clara y precisa de esos marcos delimitadores de competencias autonómicas por parte del legislador estatal. Es lo que el Tribunal denomina «principio de ley formal».

En realidad, desde sus primeros años de funcionamiento, el Tribunal Constitucional insistía, pese a la concepción material antes apuntada, en que el instrumento para establecer las bases con posterioridad a la Constitución era la ley «dado el carácter fundamental y general de las normas básicas» aunque pueda haber algunos supuestos en los que «el Gobierno podrá hacer uso de su potestad reglamentaria para regular por Real Decreto, y de modo complementario, alguno de los aspectos básicos de una materia determinada» (STC 1/1982). Por tanto, el planteamiento parecía claro respecto a la configuración posconstitucional de las bases: debían establecerse por ley, sin perjuicio de que con un carácter complementario, y excepcional ${ }^{4}$, pueda acudirse al reglamento, e incluso al acto administrativo ${ }^{5}$. En ese sentido, la STC 69/1988 se considera, como hemos comprobado, leading case de esta doctrina.

El problema es que, tras esa sentencia, el Tribunal ha insistido en la importancia de fijar las bases por ley pero ha continuado aceptando en la mayoría de los supuestos que se cumplían las condiciones, hipotéticamente excepcionales, para que se puedan establecer las bases mediante normas reglamentarias o administrativas hasta que la STC 31/2010 ha contradicho expresamente esta doctrina. Ciertamente, aún antes de

4 «Ha de admitirse, pues, que, de modo excepcional, las bases estatales puedan incluirse en normas reglamentarias con rango de Real Decreto» (STC 128/1999)

5 «Excepcionalmente pueden considerarse básicos ciertos actos de ejecución cuando por la naturaleza de la materia resulten complemento necesario para garantizar la consecución de la finalidad objetiva a que responde la competencia estatal sobre las bases» (STC 48/1988). 
ese pronunciamiento, el Tribunal no había extraído las consecuencias a la concepción formal de las bases que predicaba. En la práctica, la «preferencia de la ley» se había convertido en una búsqueda de la conexión de la norma básica reglamentaria con una norma legal que tuviera ese carácter para justificar la inclusión de las bases en decretos o incluso en órdenes ministeriales, cuanto no en actos de ejecución. El seguimiento de la jurisprudencia constitucional nos muestra que el Tribunal no ha sido consecuente con su propia doctrina formalizadora con excepciones. Ocurre, por el contrario, que esa concepción material en cuanto a la fuente de lo básico se ha consolidado pero con unas consecuencias distintas a las originarias. Si en el proceso de construcción del Estado autonómico sirvió, como se ha explicado, para que las CCAA pudieran ejercer sus facultades competenciales de desarrollo normativo aún en ausencia de bases expresamente establecidas por el Estado; después, más allá de generar una indeterminación contraria al principio de seguridad jurídica, permite al Estado soslayar cualquier límite, tanto en su estructura formal como en el alcance de su actuación.

La STC 188/2001 constituye un buen ejemplo de la renuncia del Tribunal Constitucional a imponer los elementos formales en la determinación inicial de lo básico. Por ello, el voto particular del magistrado Viver a esa sentencia tiene un sentido más trascendente que la mera discrepancia con la interpretación aceptada por la mayoría. Indica, tras la experiencia de doce años como magistrado, que el problema no es privativo de este asunto ${ }^{6}$. A su juicio, es un nuevo ejemplo de una larga y constante jurisprudencia constitucional en la que tras la expresa proclamación de lo que la STC 69/1988 denominaba "principio de ley formal», al aplicarlo a los casos concretos descubre invariablemente que todos ellos constituyen una excepción justificada de dicho principio. Así, más de un decenio después de la formulación expresa de ese principio y tras mencionarse en numerosas sentencias sólo se conocían sus excepciones. Por ello, indica Viver que quizás había llegado el momento de replantearse la cuestión desde su raíz. Concretamente en las actuales circunstancias, nos dice, «el Tribunal debería decidirse a aplicar el principio solemnemente proclamado, a justificar con argumentos fuertes sus excepciones al objeto de que éstas sean tales, o, en caso contrario, estimo preferible, por razones de seguridad jurídica entre otras, abandonar expresamente la exigencia de los mencionados requisitos formales».

Este voto particular denuncia con rotundidad, desde el interior del propio Tribunal, el carácter puramente retórico que el principio de ley formal ha asumido en la interpretación constitucional de la articulación normativa bases-desarrollo. Sin embargo, la alternativa planteada no era adecuada. El reconocimiento del principio de ley formal no era una opción del Tribunal frente a otras posibles, sino que tiene importantes apoyos en una adecuada articulación del sistema de fuentes, el respeto al carácter de contenido mínimo uniforme de las bases, la seguridad y certeza en la

${ }^{6}$ Este voto particular tiene el valor simbólico de ser el último elaborado por este magistrado antes de abandonar el Tribunal. La sentencia es de 20 de septiembre de 2001 y la renovación de los cuatros magistrado elegidos por el Congreso de los Diputados, entre los que se encuentra Viver, junto a Cruz Villalón, González Campos y Mendizábal, se publica en el BOE el 7 de noviembre. 
ordenación del reparto competencial o, incluso, en el principio democrático vinculado a la protección de las minorías. Por ello, para garantizar una adecuada articulación normativa bases-desarrollo, desde los presupuestos apuntados, el Tribunal Constitucional debía extraer las consecuencias jurídicas del principio de ley formal: efectuar un control estricto de las excepciones y, en consecuencia, declarar la inconstitucionalidad formal de las normas infralegales que pretendan la delimitación de lo básico sin justificar adecuadamente las excepciones a la elusión de la ley formal.

\subsection{El alcance o extensión de las bases}

Pero la concepción material trasciende al rango de las fuentes a través de las cuales se incorporan al ordenamiento las normas básicas. Más allá de la estructura formal de lo básico, incide también en su alcance y contenido, impidiendo a las CCAA el despliegue de políticas propias. Son dos aspectos imbricados pero distintos. Es evidente que el rango condiciona el contenido; si lo básico se incluye en un reglamento o en un acto administrativo será más detallado y tenderá a agotar la regulación de la materia mientras que si se recoge en una ley parece más lógico que se limite a establecer un mínimo normativo común o incluso tenga un carácter principial. En cualquier caso, nos interesa destacar que, más allá del rango de las normas básicas, se han eliminado los límites a la libertad del legislador estatal también en el alcance o extensión de su regulación en relación al desarrollo normativo autonómico. Ello ha producido la expansión del perímetro de lo básico en las distintas materias hasta impedir, en su envés, el despliegue de la competencia autonómica.

Desde esta perspectiva, las bases empezaron configurándose como «una regulación normativa uniforme y de vigencia en toda la Nación, con lo cual se asegura, en aras de intereses generales superiores a los de cada Comunidad Autónoma, un común denominador normativo, a partir del cual cada Comunidad, en defensa del propio interés general, podrá establecer las peculiaridades que le convengan dentro del marco de competencias que la Constitución y su Estatuto le hayan atribuido sobre aquella misma materia» (STC 1/1982/1). Por tanto, se garantizaba la diversidad, a partir de la unidad, esto es, un mínimo normativo común y un desarrollo también normativo diverso, más allá de la ejecución o aplicación de esas bases.

El problema es que no se han concretado los parámetros de control de la configuración de ese mínimo común básico por el legislador estatal. La identificación de lo básico con «principios»o «criterios generales de regulación» que hacía la primera jurisprudencia (SSTC 32/1981/6; 25/1983/4) no parece fácil de mantener en cuanto la regulación común en todo el Estado debe alcanzar directamente a sus destinatarios, por lo que no pueden ser meros principios y su alcance va a depender de las distintas materias. En consecuencia, al aplicar esta doctrina, el único límite efectivo que el Tribunal Constitucional parecía imponer al legislador básico estatal era la genérica prohibición de no vaciar el espacio competencial autonómico de desarrollo normativo. En la citada sentencia, pionera en abordar la cuestión, sostenía el Tribunal que el 
establecimiento por parte del Estado de las bases no puede llegar a tal grado de desarrollo que deje vacía de contenido la correlativa competencia de la CA (STC 1/1982/1), lo que sucedería si una regulación fuese excesivamente minuciosa o detallada (STC 147/1991).

Incluso se ha aceptado en la práctica ese vaciamiento desde distintos criterios, si bien con un carácter excepcional y justificado. Así, desde un criterio teleológico entiende el Tribunal que «la distinción entre lo básico y lo que no lo es resulta inutilizable por artificiosa aplicada a los preceptos integrantes de una medida que sólo puede ser considerada y aplicada como unidad» (STC 179/1985/1) ${ }^{7}$. La homogeneidad requerida en el concreto sector normativo justifica unas detalladas bases que agotan la regulación. También se ha justificado la extensión de lo básico desde la doctrina de lo «básico por conexión». Así, ya en la STC 25/1983/4 señalaba el Tribunal que «todo aquello que sea preciso para la preservación de la normativa de una institución considerada como básica debe ser entendido asimismo como bases por vía de consecuencia o conexión. En la práctica, los límites a la extensión o alcance de las bases se han aplicado fundamentalmente a cuestiones de carácter organizativo, como la inclusión en las bases de la organización y funcionamiento interno de órganos colegiados (STC 50/1999; 275/2000).

En conclusión, podemos afirmar que ha faltado una doctrina que garantice desde parámetros claros el respeto al espacio competencial de desarrollo normativo autonómico cuando el legislador estatal ejercita su libertad de configuración de las bases, siquiera a partir del lábil criterio del no vaciamiento de la competencia autonómica ${ }^{8}$. El problema en este sentido es que no dejar vacía de contenido la competencia autonómica se ha identificado con la posibilidad de que la Comunidad pueda actuar de alguna forma en el ámbito concreto objeto de la regulación básica. Sin embargo, no era ese el sentido con el que fue configurada la relación entre las bases del Estado y el desarrollo normativo de las CCAA sino que, como señalaba García de Enterría, se trataba de garantizar, por un lado, la actividad normativa y, por otro, que a través de ella se pudiera desarrollar una política propia (E. García de Enterría, 1985, 313).

\section{LA DESFORMALIZACIÓN E ILIMITADA EXPANSION DE LO BÁSICO A PARTIR DE LAS STC 31/2010}

La STC 31/2010 ha reconocido de forma expresa, y ha justificado, la desformalización de lo básico al cuestionar la definición de esta categoría competencial que pretendía introducir el Estatuto de Cataluña. En puridad, cuando ese Estatuto o el de Andalucía (art. 42.2.2. ${ }^{\circ}$ ) indican que las bases deben fijarse en normas con rango

${ }^{7}$ Cfr. en sentido crítico, E. Albertí Rovira, 1986.

${ }^{8}$ Como indica X. Arzoz, «el criterio del no vaciamiento no hace más que sopesar la acción normativa estatal y excluir eventuales excesos pero no ayuda a definir en positivo ni a acotar lo básico» (2016, 211). 
de ley están recogiendo la doctrina del propio Tribunal Constitucional, como hemos comprobado. Un Estatuto no debería indicar en qué fuente van a incluirse las bases estatales pues la forma de lo básico es un componente de la definición de esta categoría competencial de naturaleza constitucional. Sin embargo, cuando se limita a recoger la doctrina del Tribunal Constitucional estamos ante una norma programática. Se puede sostener que esa reiteración es innecesaria (juicio de oportunidad) pero no que es inconstitucional (juicio de constitucionalidad). Sin embargo, el Tribunal Constitucional ha declarado la inconstitucionalidad de la previsión estatutaria catalana y lo más trascendente es que para ello ha eliminado el mencionado principio de «ley formal», al que venía refiriéndose, aunque sin aplicarlo, desde su primera doctrina con un eslabón fundamental en la STC 69/1988.

Sostiene el Tribunal Constitucional en el Fundamento Jurídico 60 de la STC 31/2010 que el Estatuto presenta como excepción la inclusión de las bases estatales en reglamentos o actos de ejecución cuando son «elementos de la definición del contenido y alcance de la competencia atribuida al Estado», esto es, de la definición de esa categoría competencial. Para alcanzar esa conclusión niega el valor de doctrina de referencia a la STC 69/1988, y trae a colación la STC 235/1999 para defender que la inclusión de las bases en reglamentos o actos de ejecución no tiene un carácter excepcional. La argumentación es discutible y no sólo porque, como hemos visto, son muchas las sentencias que desde 1981 se han referido expresamente al carácter excepcional o complementario de la inclusión de lo básico en normas reglamentarias posconstitucionales. Ocurre, además, que la STC 235/1999 es una de las sentencias fundamentales en relación al régimen jurídico de las cajas de ahorro, esto es, se refiere a las bases en «ordenación, crédito y seguros». Desde los inicios de la actividad del Tribunal Constitucional estaba asentada la doctrina de la interpretación más desformalizada y extensiva de la bases estatales en materia económica en general y en «ordenación del crédito, banca y seguros en particular» (SSTC 57/1983; 48/1988, entre otras). Por ello, en esa materia se había aceptado con normalidad la inclusión de bases estatales en actos de ejecución (J.M. Pemán Gavín, 2008, 2342-2343). Sin embargo, la STC 31/2010 aplica como doctrina general la establecida en relación a la materia económica con carácter especial. Reflejo de esa singularidad de las bases en ese ámbito es que al desglosar su competencia sobre «cajas de ahorro» los Estatutos de Cataluña y Andalucía indicaban expresamente que en ese caso concreto las bases pueden ser no sólo estándares mínimos o principios sino también «reglas», en un supuesto también declarado inconstitucional en el Estatuto de Cataluña (no en el de Andalucía, obviamente, pues no fue recurrido) precisamente por definir las bases. Interesa destacar que se trata del único supuesto en el que al desglosar una materia el Estatuto se detiene en la configuración formal de las bases. Y esto no lo hace por casualidad sino que pretende recoger la doctrina anterior del Tribunal Constitucional. Por ello, resulta paradójico que en la STC 31/2010 el Tribunal presente la doctrina de la STC 235/1999 sobre las bases como la doctrina general para sostener ahora que la inclu- 
sión de las bases en reglamentos o actos de ejecución no es una excepción sino que forma parte de la definición de la categoría (J.A. Montilla, 2015, 104; X. Arzoz, 2016, 215).

Ciertamente, esta declaración de inconstitucionalidad supone un paso atrás definitivo en el proceso de formalización de lo básico a través de su inclusión en ley como regla general y su determinación expresa, sin perjuicio de su regulación excepcional o complementaria en otras fuentes infralegales o incluso en actos de ejecución.

Por tanto, los Estatutos de Autonomía de segunda generación habían pretendido interponer límites a la libertad de configuración del legislador básico estatal al definir la estructura formal de las bases e incorporar la exigencia de que las Comunidades deberían poder desarrollar políticas propias en el marco de competencias compartidas. Sin embargo, lo primero fue declarado inconstitucional por el Tribunal Constitucional en la STC 31/2010, como hemos explicado, y lo segundo ha sido soslayado en su doctrina posterior pese a no haber sido cuestionado en la mencionada sentencia y seguir formando parte, por tanto, del bloque de la constitucionalidad. En definitiva, conforme a esa doctrina el Estatuto de autonomía no puede condicionar ni la estructura ni el alcance las bases, como ha indicado de forma expresa en sentencias posteriores y analizamos en otro apartado.

Lo que nos interesa destacar ahora es que el Tribunal Constitucional ha aceptado una libertad del legislador estatal para determinar lo básico prácticamente absoluta, tanto en su estructura formal como en su alcance, que éste, lógicamente, está ejerciendo. Esa expansión de las bases provoca tres formas de respuesta por parte de las CCAA, todas ellas negativas. En primer lugar, la inactividad autonómica al haber cubierto el Estado su espacio de actuación. Resulta habitual en el proceso de incorporación de normas europeas al ordenamiento interno. De esta forma, al no ejercer su responsabilidad normativa pierde, de facto, la facultad competencial estatutariamente reconocida. La segunda respuesta es la técnica de la reproducción en normas autonómicas de las bases estatales cuando posea título competencial para el desarrollo normativo. Ha sido criticada, con razón, por el Tribunal Constitucional como una «peligrosa técnica legislativa» (STC 62/1991) y ha justificado después, como veremos, la recuperación de la cláusula de prevalencia para inaplicar normas autonómicas cuando se modifican las bases que reproducían (STC 102/2016). La reproducción de normas básicas estatales en el ordenamiento autonómico es una técnica legislativa que no puede considerarse per se inconstitucional cuando no se modifica el contenido normativo (STC 61/1993), aunque puede provocar problemas jurídicos de interpretación. La tercera respuesta, y sin duda la más habitual, es el planteamiento de un conflicto de competencias ante el Tribunal Constitucional. Buena parte de las normas básicas del Estado son recurridas por alguna Comunidad Autónoma al considerar que se ha invadido el espacio competencial autonómico. Esto ha convertido a nuestro modelo en esencialmente conflictivo. Pese a la importancia que han adquirido las comisiones bilaterales previstas en el artículo 33.2 LOTC para alcanzar acuerdos, son muy numerosos los conflictos competenciales que llegan al Tribunal Constitucional. 
Los datos en comparación con Alemania resultan elocuentes. Mientras allí se plantea de media apenas un conflicto competencial al año, en España suelen superar los treinta (E. Aja, 2014) $)^{9}$. El motivo primero de esta conflictividad está en la no participación de las CCAA en el proceso de aprobación de la ley a través de sus gobiernos como órganos de dirección política presentes en un Consejo territorial, pero también ha influido, a posteriori, la doctrina del Tribunal Constitucional, aceptando en la práctica la extensión de las bases sobre las distintas materias planteada por el legislador estatal.

La STC 93/2015 (Función social de la vivienda en Andalucía) refleja bien el alcance y las consecuencias de esta forma de entender las bases en la doctrina del Tribunal que imposibilita, en la práctica, el desarrollo normativo autonómico ${ }^{10}$. Esta sentencia ha declarado la inconstitucionalidad de la disposición normativa autonómica al considerar que su regulación se proyecta sobre un ámbito material (los supuestos de especial vulnerabilidad en las ejecuciones hipotecarias) que ya había sido reglado por el Estado de forma completa y, en ese sentido, la regulación había sido agotada. No cabe, por tanto, desarrollo normativo autonómico sino, en su caso, la adopción de medidas de fomento.

Puede comprenderse bien el debate que ha originado está doctrina, reflejado en los votos particulares a la sentencia. Nos dice el Tribunal que cuando el Estado regula una materia en virtud de un título competencial horizontal para establecer las bases puede agotar la regulación y la Comunidad Autónoma no tiene espacio alguno de actuación normativa para el desarrollo de una política propia. Se impide a la Comunidad adoptar cualesquiera medidas normativas en el ámbito que ha ocupado íntegramente la acción pública estatal, aunque no sean contradictorias, en cuanto vendría a romper la acción coherente de la citada política pública estatal. La Comunidad

9 Puede consultarse una completa tabla con los datos comparados de España y Alemania en X. Arzoz, 2016, 223.

${ }^{10}$ El conflicto se había planteado en torno a la adopción por la Comunidad Autónoma de Andalucía de medidas de protección aplicables al problema social derivado del lanzamiento de su vivienda en un procedimiento de ejecución hipotecaria de personas en situación de emergencia social. El Estado, en ejercicio de su título competencial horizontal sobre la ordenación general de la actividad económica, había establecido como básicas dos medidas para atender a ese problema social: el aplazamiento del lanzamiento durante dos años (elevado a cuatro en 2015) cuando existiera una situación de emergencia social y la creación de un fondo de viviendas procedentes de las entidades financieras para ofrecerlas en alquiler social a las personas que hubieran sido desahuciadas (Real Decreto-ley 27/2012, de 15 de noviembre, de medidas urgentes para reforzar la protección a los deudores hipotecarios). Por su parte, la Comunidad Autónoma de Andalucía, en ejercicio de su competencia exclusiva en materia de vivienda (art. 56 del Estatuto de Autonomía) había previsto una amplia regulación de la función social de la vivienda en la que se incluye una medida distinta en relación a la situación mencionada: la expropiación temporal del uso de las viviendas objeto de ejecución hipotecaria en estos supuestos de emergencia social para que sus anteriores propietarios pudieran seguir ocupándolas en alquiler social (Disposición Adicional segunda del Decreto-ley 6/2013, de 9 de abril, de medidas para asegurar el cumplimiento de la función social de la vivienda). Esa disposición fue recurrida por el Gobierno del Estado al entender que vulneraba el art. 149.1.13 CE. 
Autónoma ha perdido, por tanto, la facultad de desarrollo normativo que caracteriza a las competencias compartidas.

En puridad, esta doctrina no resulta sorprendente si atendemos a las sentencias que venía dictando el Tribunal, especialmente a partir de la STC 34/2013. La libertad de configuración del legislador básico estatal se ha ejercido en la práctica sin apenas límites. No sólo ha desaparecido el límite sobre la fuente en que debe contenerse lo básico (STC 31/2010) sino también el referido a su alcance y contenido, concretado en el principio de «no vaciamiento» de las competencias autonómicas. En cuanto se reconoce expresamente que el Estado puede agotar la regulación de la materia parece evidente que queda vaciada la competencia de desarrollo normativo. Se elimina, con ello, el límite del «no vaciamiento», cuya limitación paulatina ya habíamos advertido.

De esta forma, la doctrina del Tribunal Constitucional ha mutado la naturaleza de las bases de Estado. La consecuencia política es la aminoración del espacio competencial autonómico y la evidente imposibilidad de desarrollar políticas propias en ejercicio de competencias compartidas. De esta forma, se contradice el propio fundamento constitucional de esta categoría competencial pues los poderes normativos autonómicos no proceden del poder general del Estado sino de la Constitución (F. Balaguer, 1992, 208-209).

En definitiva, una vez eliminados de forma expresa en la sentencia sobre el Estatuto de Cataluña (STC 31/2010) los obstáculos al rango formal de las normas básicas, se ha consolidado también una concepción material en su alcance o extensión. Lo han advertido los votos particulares a distintas sentencias posteriores a la STC 31/2010, entre otras a las SSTC 34/2013, 74/2014 o 170/2014, y tiene su punto de referencia en la mencionada STC 93/2015. Como explica el voto particular del magistrado Xiol Rius, se ha producido una inflexión recentralizadora al establecerse una comprensión del concepto de bases que superaba el sentido natural en el lenguaje de esta expresión, deducido de su uso literal, semántico y pragmático, posibilitando que el Estado estableciera no sólo criterios de ordenación general de un sector de la economía de exclusiva competencia autonómica sino pormenorizadas regulaciones de aspectos materiales concretos que agotaran la consecución del objetivo perseguido por el Estado, en cuyo marco debería desenvolverse, ya de manera imposible, la hipotética normativa sectorial autonómica.

El título competencial aducido por el Estado en este supuesto para plantear la inconstitucionalidad de la actuación autonómica es la «ordenación general de la actividad económica» (art. 149.1.13 CE), título horizontal que habilita al Estado para establecer las bases y la coordinación en cualquier materia que afecte a la actividad económica. En lo que ahora interesa, parece claro que el título alcanza a acciones o medidas singulares en los distintos sectores y las competencias autonómicas no son un obstáculo para el despliegue de ese título competencial del Estado, con dos salvedades. En primer lugar, «a condición de que el referido título competencial no alcance a incluir cualquier acción de naturaleza económica, si no 
posee una incidencia directa y significativa sobre la actividad económica general (STC 21/1999/5); en segundo lugar, a reserva de que el uso que haga el Estado de esta atribución transversal no agote el título competencial más específico que incumbe a la Comunidad Autónoma (STC 34/2013/12). Ocurre que se ha impuesto la primera afirmación («las competencias autonómicas no son un obstáculo para el despliegue de ese título competencial») a la última («el uso que haga el Estado de esta atribución transversal no agote el título competencial más específico que incumbe a la Comunidad Autónoma»). La STC 93/2015 refleja nítidamente que el despliegue de la competencia estatal impide el complemento normativo autonómico y reduce el alcance del título competencial más específico de la Comunidad Autónoma a la mera actividad de fomento. Una vez ejercitada la competencia estatal de regulación de las bases o planificación de un sector económico de competencia de la Comunidad Autónoma, ésta queda «expropiada» de esa competencia, esto es, bloquea el posible desarrollo normativo autonómico. En definitiva, expande el alcance de las bases hasta provocar el «vaciamiento» de la competencia autonómica, único límite que, al menos formalmente, había mantenido hasta ahora el Tribunal, en cuanto se dice expresamente que la regulación queda agotada con la actuación del Estado. Este es uno de los aspectos más trascendentes que aporta esta sentencia en el proceso de ilimitada expansión de lo básico. Primero se admite que la competencia del Estado en virtud del 149.1.13 CE puede referirse a sectores determinados, y no a la política económica general (STC 235/1999). Luego se afirma que, en esos sectores de exclusiva competencia autonómica, el Estado puede establecer, en virtud de su título horizontal, pormenorizadas regulaciones de aspectos materiales concretos que agoten la consecución del objetivo perseguido por el Estado, superando el sentido natural de las bases (STC 34/2013) y ahora, dando un paso más, considera que puede agotar la regulación de ese concreto sector económico, sin que resulte posible la actuación normativa autonómica aun cuando ambas regulaciones, estatal y autonómica, pueden ser compatibles e incluso complementarias.

Este último dato es relevante. El Tribunal no ha comprobado siquiera si existe contradicción o incompatibilidad entre las medidas previstas en la legislación básica estatal y en la autonómica. Se ha limitado a constatar la «interferencia» en cuanto la adición por la norma autonómica de un nuevo mecanismo orientado a satisfacer esa misma situación de necesidad vendría a romper el carácter coherente de la acción pública del Estado. En definitiva, el criterio de «no contradicción» con las bases estatales ha sido sustituido por una hipotética interferencia para una actuación coherente del Estado. Pero la interferencia no puede ser suficiente para impedir un desarrollo normativo autonómico constitucionalmente reconocido. Como recuerda el voto particular de la magistrada Asúa Bastarrita, «el control de constitucionalidad de normas en el ámbito de las competencias compartidas o de las competencias exclusivas autonómicas sobre las que pueden incidir las competencias transversales estatales (como el art. 149.1.13 CE) no tiene como cometido enjuiciar la mayor o menor 
compatibilidad o coherencia entre políticas, medidas u objetivos estatales o autonómicos sino sólo la posible contradicción normativa».

Se impide, por tanto, la divergencia entre las respuestas normativas del Estado y las CCAA en ejercicio del desarrollo normativo, aun cuando no exista contradicción. Según la STC 93/2015, «la concurrencia de figuras jurídicas dispares sobre una misma realidad hace difícil la aplicación conjunta de ambas medidas». Así, por la simple razón de que la norma autonómica supone una intervención pública adicional a la diseñada por el Estado, «interfiere al menos el ejercicio de la competencia estatal en materia de ordenación económica (art. 149.1.13) al realizar una regulación que se proyecta sobre un ámbito material ya regulado por el Estado».

Sin embargo, la competencia autonómica de desarrollo normativo no puede reducirse a adaptar la respuesta básica estatal a un determinado supuesto en el territorio. Esa previsión es aplicable en la Comunidad Autónoma por su carácter básico, pero ello no impide que en el desarrollo normativo autonómico se adopten otras medidas complementarias, esto es, se desarrollen políticas propias como deriva tanto del origen constitucional de la competencia de desarrollo normativo autonómico como de la referencia expresa en los Estatutos de Autonomía, y del bloque de la constitucionalidad, por tanto, sin que haya sido cuestionado por el Tribunal Constitucional. De hecho, en el supuesto de esta sentencia, la suspensión temporal del lanzamiento y la expropiación del uso de la vivienda son dos medidas adoptadas por órganos distintos en ejercicio de sus competencias respectivas, básica y de desarrollo normativo, que pueden ser compatibilizadas en cuanto la vivienda puede ser usada mientras está suspendido el lanzamiento. Distinto es entender, como hace el Tribunal, que el «carácter coherente de la acción pública en esta materia» impide cualquier divergencia en la actuación normativa y reduce el ámbito de actuación autonómico a la aplicación de la medida prevista por el Estado en su territorio. No debería ser así. El carácter divergente de la actuación autonómica en un determinado supuesto en ejercicio de sus competencias se enmarca en el principio constitucional de autonomía. No se puede exigir una coherencia que, como indica el voto particular de la magistrada Asua Bastarrita, es un eufemismo de uniformidad. El parámetro de control no puede ser la adaptación a las medidas concretas previstas por el Estado sino al fin que justifica dichas medidas, en este caso la protección social frente a los desahucios. Nos hallamos ante medidas distintas, incluso sucesivas en el tiempo, para afrontar un determinado problema. Por ello, la compatibilidad no parece difícil en cuanto son normas de aplicación sucesiva en el tiempo, tanto formalmente como en la práctica. La suspensión temporal impide la existencia de un auto de lanzamiento y hasta que no exista éste, por cumplirse los años de suspensión previstos en la norma básica estatal, no resulta aplicable la previsión de la norma andaluza. Por tanto, la aplicación de la norma autonómica sólo se produciría cuando finalice el periodo de suspensión de los procedimientos de ejecución establecidos por el Estado pues sólo a partir de ese momento puede producirse el supuesto de hecho previsto por la norma andaluza: el lanzamiento acordado por un órgano judicial. En consecuencia, el desarrollo norma- 
tivo autonómico resulta plenamente complementario de la norma básica estatal. Sin embargo, el Tribunal Constitucional no ha atendido a este razonamiento para mantener la legislación autonómica de desarrollo y la ha considerado inconstitucional en cuanto «interfiere» en la actuación pública estatal.

En conclusión, nos encontramos ante una concepción de la relación entre las bases estatales y el desarrollo normativo autonómico que impide el despliegue de la competencia normativa autonómica no por contradecir la norma básica sino por la interferencia en la coherencia de la acción pública prevista por el Estado en ejercicio de su título competencial para establecer las bases. Para que el Estado pueda regular una determinada cuestión con el título competencial del art. 149.1.13 CE no precisa una relación directa del presupuesto habilitante (reorganización y reestructuración del sistema financiero) con la regulación concreta (medidas de emergencia social ante los desahucios) sino meramente genérica; con ese título puede agotar la regulación del objeto, vaciando de contenido normativo el título competencial de la Comunidad Autónoma; modifica la concepción del desarrollo normativo como complemento de la regulación básica regido por la «no contradicción» para sustituirlo por el de «no interferencia» en la actuación del Estado; y, en consecuencia, no sólo se impide la divergencia sino que se impone la uniformidad en el tratamiento normativo, de manera que el desarrollo autonómico debe limitarse a aplicar en el territorio, norma básica estatal. La pregunta obvia, a partir de la concepción de lo básico que expresa de forma rotunda la STC 93/2015, es cómo pueden desarrollar las Comunidades Autónomas sus políticas propias derivadas de la competencia constitucional de desarrollo normativo en el marco de las bases estatales. Con razón, han advertido los votos particulares que asistimos a un proceso de ilimitada expansión de lo básico cuya consecuencia es la recentralización política.

\section{LA IMPOSICIÓN DE LAS BASES SOBRE EL ESTATUTO DE AUTONOMÍA A PARTIR DE LA STC 31/2010}

Esta desformalización de lo básico e ilimitada expansión de su alcance en las competencias compartidas se vincula, como hemos apuntado, a la imposición de las bases sobre el Estatuto de Autonomía, que constriñe, de esta forma, su función delimitadora. Procede detenerse, por tanto, en esta cuestión.

Hasta la STC 31/2010, la mayor parte de la doctrina y el propio Tribunal Constitucional, como intentaré mostrar, entendían que al incluirse una determinada facultad en el Estatuto se ubica expresamente en el espacio competencial autonómico y ya no puede ser objeto de regulación estatal en ejercicio de su competencia para establecer las bases. Lógicamente, puede ocurrir que el estatuyente se extralimite al hacer la configuración positiva de su espacio competencial. En ese supuesto estaríamos ante un conflicto competencial que únicamente podría ser resuelto por el Tribunal Constitucional, a través del correspondiente conflicto, con la expulsión del ordena- 
miento de la norma estatutaria o su «interpretación conforme», en el sentido que el propio Tribunal Constitucional ha expresado. Pero si no era cuestionada esa previsión estatutaria, se entendía que, desde el bloque de constitucionalidad, el Estatuto podía delimitar la capacidad del Estado para establecer lo básico.

Debemos recordar, como premisa de esa posición, la singularidad de nuestro Estado autonómico y la singular naturaleza jurídica del Estatuto de Autonomía. Realizan una función que ni siquiera pueden hacer las Constituciones de los estados miembros de una federación, sino sólo la Constitución federal: la atribución de competencias a las entidades territoriales autónomas. Esa capacidad de atribución debe hacerse en el marco de la Constitución y está limitada sólo por la propia Constitución. En consecuencia, el legislador básico estatal no podría limitar a quien está habilitado por la Constitución para la atribución de competencias.

El Estatuto de Cataluña, efectivamente, pretende una delimitación negativa de las bases. Al determinar las facultades de actuación de una Comunidad Autónoma en una materia de forma implícita está limitando la capacidad delimitadora del legislador estatal. Esto no significa que esa delimitación negativa sea incólume pues el Estatuto ha podido vulnerar el marco constitucional. Pero esto es algo que deberá determinar el Tribunal Constitucional al resolver un conflicto competencial en este sentido. De esta forma no quedaría afectado el mínimo común normativo como contenido de lo básico que puede ser establecido por el Tribunal Constitucional al resolver un concreto conflicto; lo que si quedaría mediatizada era la libertad absoluta del legislador ordinario estatal para determinar las bases y para cambiarlas en cualquier momento pues ese cambio ya no provocaría únicamente la inconstitucionalidad sobrevenida del desarrollo normativo autonómico de lo básico sino que podría contradecir una norma estatutaria y, con ello, el bloque de la constitucionalidad.

Los argumentos para sostener esa posición son dos. En primer lugar, el legislador básico estatal es un poder limitado por el bloque de la constitucionalidad, en el que se incluye el Estatuto de Autonomía, sin perjuicio de que los contenidos de éste puedan ser sometidos a control de constitucionalidad. Por otro lado, el límite no afecta a su capacidad para regular lo básico en el marco delimitado por la Constitución territorial sino para redelimitar ese marco en el proceso de producción normativa de lo básico, proceso diferenciable del anterior en cuanto esta segunda operación debe atender a las normas sobre la producción del ordenamiento (F. Balaguer, 2006, 41). Además, la limitación de la capacidad delimitadora del legislador básico tiene una consecuencia positiva para el funcionamiento del Estado autonómico que no podemos soslayar: puede coadyuvar a la estabilización del contenido de lo básico en cada una de las materias competenciales. Se tiende a superar la conocida «variabilidad de lo básico» (J. García Morillo, 1996). Por tanto, estabilizar lo básico desde el bloque de la constitucionalidad es un proceso positivo e incluso necesario para el adecuado funcionamiento del Estado autonómico. Que lo haga el Estatuto y no la Constitución es la consecuencia de la posición del Estatuto en nuestro modelo y de la apatía del poder de reforma constitucional. 
Esta pretensión de dar fijeza a la delimitación de lo básico no impide al legislador estatal cambiar la regulación para adaptarla a los cambios de la sociedad, esto es, no petrifica el tratamiento normativo de una determinada cuestión, sino que incorpora un parámetro más preciso a través del Estatuto.

Esta interpretación había sido rechazada por un sector doctrinal a partir de considerar que la Constitución remite al legislador básico y, en consecuencia, lo que éste determine en cualquier momento prevalece sobre las previsiones estatutarios (T. de la Quadra-Salcedo Janini, 2004). Sin embargo, a mi juicio, no era esa la posición del Tribunal Constitucional antes de la STC 31/2010. Por un lado, el Tribunal no había incluido a la legislación básica en el bloque de la constitucionalidad; por otro, ha establecido el sometimiento de ésta no sólo a la Constitución sino también a los Estatutos. Recuérdese el pronunciamiento de la STC 141/1993 cuando establece que «tal regulación sólo corresponde hacerla al Estado mediante normas de carácter básico en la medida en que así lo permitan la Constitución y los Estatutos de Autonomía». A mi juicio, la tesis de que la legislación básica prevalece sobre lo establecido en los Estatutos de Autonomía soslaya las características singulares de nuestro modelo de organización territorial. Según esa posición, la Constitución delimita completamente las competencias estatales, de forma que quedaría constitucionalmente cerrado el reparto competencial. Sin embargo, la mera lectura del art. 149.1 CE permite comprobar que esto no es así. Por motivos genéticos, a los que antes hacíamos referencia, nada tiene que ver nuestro título VIII, y en concreto el art. 149.1 CE, con el título competencial de otras constituciones de Estados descentralizados en las que se concretan las competencias del Estado.

La STC 247/2007 parecía avalar esta interpretación en un doble sentido. Por un lado, en cuanto destaca que el art. 149.1 CE no describe con detalle el contenido de las materias de competencia estatal y, por otro, en cuanto en determinados casos sólo incluye algunas funciones en relación a la materia, y no toda ella. Sin duda, el caso más significativo es el de las bases. El límite que se establece en la sentencia es que la regulación normativa estatutaria no desnaturalice el contenido que sea propio de cada materia, «que permita su recognoscibilidad como institución» (FJ 10). De esta forma, está estableciendo un límite a la delimitación estatutaria del espacio competencial autonómico, que lógicamente está sometido al control de constitucionalidad, pero ello no significa habilitación para que una hipotética delimitación estatal a través de normas básicas se imponga sobre lo establecido en los Estatutos. En el caso del alcance de lo básico esta cuestión es manifiesta. Es el legislador estatal quien hace esa delimitación y está sometido al Estatuto pues el Estatuto forma parte del bloque la constitucionalidad. Cuestión distinta sería plantear que éste no es el modelo ideal y debería ser la Constitución quien hiciera la delimitación de lo básico. Sin embargo, no es así en nuestro ordenamiento.

Esta interpretación no limita, obviamente, la capacidad del Tribunal Constitucional. Este puede declarar inconstitucional un precepto estatutario por invadir las bases estatales, pero no simplemente porque el legislador estatal lo considere básico 
sino porque al interpretar la Constitución el Tribunal Constitucional ha considerado básico ese determinado aspecto de la materia competencial ahora incluido en el Estatuto. Incluso resulta posible que se produzca la inconstitucionalidad sobrevenida de la regulación estatutaria al considerar que un nuevo contexto obliga a ensanchar las bases estatales para el cumplimiento de su función. Lo que rechazamos es que esto pueda derivar de la actuación del legislador ordinario estatal, imponiéndose de esta manera al estatutario.

Sin embargo, la STC 31/2010 ha rechazado la función delimitadora del Estatuto en las competencias compartidas. El Tribunal sostiene en esta sentencia que no existen obstáculos constitucionales para el desglose de facultades competenciales autonómicas en el Estatuto, esto es, para que concrete, también en las competencias compartidas, las facultades competenciales que se ubican en el espacio autonómico. Sin embargo, a su vez, ha destacado que el legislador básico estatal no resulta obligado por la delimitación negativa que hace el Estatuto al concretar las competencias autonómicas. No existe «blindaje» derivado de la concreción de las facultades competenciales pues esa concreción no conlleva una limitación del ámbito competencial de lo básico, esto es, no puede restringir el ámbito competencial atribuido al Estado por la Constitución ${ }^{11}$.

A nuestro juicio, no existe incompatibilidad entre la inexistencia de blindaje y la vinculación del legislador básico estatal a los contenidos estatutarios. Ocurre que al detallar con exhaustividad las competencias autonómicas condiciona la delimitación de lo básico, sin que ello contradiga la afirmación de que corresponde finalmente al Tribunal Constitucional en caso de conflicto.

Sin embargo, la STC 31/2010 lo interpreta de forma distinta, seguramente por la influencia del áspero debate político en el que se produce esta sentencia. Si el Estatuto es una ley orgánica más, y su función materialmente constitucional es sólo una afirmación «doctrinal o académica»; las categorías y principios han sido objeto de una definición jurisdiccional perfectamente acabada o los términos del Estatuto sólo pueden interpretarse en los límites de la doctrina del Tribunal Constitucional, resulta claro que está impidiendo la función delimitadora del Estatuto y configura al propio Tribunal como delimitador de las competencias compartidas, en lugar de órgano de resolución de conflictos.

Las consecuencias de esta doctrina se advierten con claridad en la STC 168/2016. El Estatuto de Autonomía de Asturias reconocía desde 1981 personalidad jurídica a las parroquias rurales características de su territorio. Sin embargo, la reforma de la Ley de Bases de Régimen Local llevada a cabo por la Ley 27/2013, de Racionalización y Sostenibilidad de la Administración Local, básica en virtud del artículo 149.1.18 $\mathrm{CE}$, niega personalidad jurídica a los entes locales menores al municipio, entre los que se encuentran estas parroquias asturianas. Existe, por tanto, una contradicción sobrevenida entre el Estatuto de Autonomía y esta nueva regulación básica, esto es,

${ }^{11}$ Cfr. en este sentido en la doctrina, T. De la Quadra-Salcedo Janini, 2005, pp. 185-187. 
entre la regulación establecida unilateralmente por el Estado y la acordada muchos años antes con el territorio en el Estatuto al establecer los rasgos característicos de la organización interna de ese territorio. El Tribunal resuelve el conflicto en favor de la nueva ley básica del Estado. Aplicando la doctrina de la STC 31/2010, considera que esta legislación del Estado aprobada en 2013 se impone sobre el Estatuto de autonomía. No sólo se niega cualquier alcance a la función «materialmente constitucional» del Estatuto, a su inclusión en el bloque de la constitucionalidad o de la Constitución territorial sino que ni siquiera se acepta la aplicación del principio de especialidad en cuanto las parroquias rurales constituyen una figura específica de Asturias.

A partir de esta sentencia, en todos los demás casos en los que el Tribunal ha debido enjuiciar el contenido de la Ley 27/2013, ha rechazado la utilización como parámetro de constitucionalidad del Estatuto de Autonomía. Considera que «una norma estatutaria de régimen local no puede funcionar como límite al ejercicio de la competencia constitucionalmente atribuida al Estado», «no puede imposibilitar que éste reforme las bases», «ni suponer que las nuevas bases dejen de operar como mínimo común normativo, esto es, que sean inaplicables en las Comunidades Autónomas en una Comunidad Autónoma por virtud del derecho local incluido en su Estatuto» (SSTC 44/2017, 45/2017 o 54/2017, entre otras). Esto le lleva a desestimar todos los motivos de inconstitucionalidad que se basan en la infracción de normas de Derecho local estatutario. El contenido estatutario referido a régimen local no puede ser, por tanto, parámetro de constitucionalidad, de la legislación del Estado sobre esa materia, con lo que se profundiza el proceso de devaluación del Estatuto de Autonomía e incluso de ausencia de Constitución territorial pues una cuestión tan relevante como el régimen local dependerá de la legislación coyuntural del Estado, y no de la Constitución, que apenas se ha referido a ello, ni del Estatuto de Autonomía.

\section{LA APLICACIÓN DE LA CLÁUSULA DE PREVALENCIA PARA LA INAPLICACIÓN DE NORMAS AUTONÓMICAS CONTRARIAS A NORMAS BÁSICAS SOBREVENIDAS}

El último aspecto en relación a las competencias compartidas que debe mencionarse es la recuperación de la cláusula de prevalencia para inaplicar normas autonómicas cuando contradigan normas básicas aprobadas con posterioridad que ha efectuado el Tribunal Constitucional a partir de la STC 102/2016. El cambio no se vincula, en este caso, a la STC 31/2010 aunque podemos presumir que responde también al proceso de devaluación del espacio competencial autonómico cuyo hito fundamental es esa sentencia.

En la doctrina tradicional del Tribunal Constitucional, cuando se aprobaba una nueva regulación básica que contradecía normas autonómicas vigentes, éstas no resultaban derogadas ni desplazadas. Por tanto, los aplicadores jurídicos, jueces y admi- 
nistración, no podían inaplicarla en virtud de esta inconstitucionalidad sobrevenida; debían plantear una cuestión de inconstitucionalidad para que el Tribunal pudiera declarar la inconstitucionalidad de las normas autonómicas, expulsándolas del ordenamiento, en virtud del monopolio de control sobre las normas legales posconstitucionales que tiene el Tribunal Constitucional.

Sin embargo, en la STC 102/2016 se aparta de manera expresa de esa doctrina. En ese supuesto concreto considera el Tribunal que el conflicto puede resolverse directamente dando preferencia a la legislación estatal, que desplaza a la autonómica en virtud del principio de prevalencia (art. 149.3 CE). La norma autonómica no resulta anulada sino desplazada.

En cualquier caso, no se plantea como un supuesto general sino excepcional, cuando concurra la circunstancia que se advierte en ese caso: la ley autonómica se limitaba a reproducir una norma básica que posteriormente ha sido modificada por el Estado. Por tanto, el desplazamiento se presenta como la «solución lógica a una situación provocada por la propia Comunidad Autónoma que ha incumplido el deber de inmediata acomodación de su legislación de desarrollo a la nueva legislación básica» (FJ 6).

Las razones que aporta el Tribunal para este cambio en su doctrina son tres. En primer lugar, no hay dudas sobre la constitucionalidad de la norma básica pues el Tribunal ya se había pronunciado sobre el carácter básico de la regulación estatal (FJ 6); en segundo lugar, la contradicción no derivaba de una pretensión competencial específica de la Comunidad Autónoma sino de la deficiente técnica legislativa consistente en reproducir la legislación básica estatal (FJ 2); en tercer lugar, quien se enfrenta a la contradicción en este caso no es un órgano judicial sino el «operador jurídico primario», la administración, destinatario por excelencia de la regla de la prevalencia del art. 149.1.3 CE (J.L. Requejo Pagés, 2016, 237). Cuando se cumplen estos requisitos, considera el Tribunal que la prevalencia puede ser una herramienta útil para que las relaciones entre los ordenamientos estatal y autonómico se desarrollen con fluidez.

Esa doctrina se ha aplicado posteriormente en las SSTC 116/2016 o 127/2016. No obstante, mientras en el primer caso sólo una magistrada, Asúa Bastarrica, había discrepado de este cambio de doctrina, en la última han sido cinco los votos discrepantes. Se cuestiona en cuanto supone la quiebra del principio de control concentrado que caracteriza a nuestra jurisdicción constitucional aunque también puede resultar cuestionable que se deje a la administración esa decisión de valorar si estamos ante una norma autonómica que reiteraba normas básicas sin siquiera un control judicial.

Resulta importante constatar que en esta primera interpretación, la aplicación de la regla de la prevalencia sólo puede hacerla la administración, pero no los jueces. Estos continúan obligados, según la doctrina del Tribunal Constitucional, a plantear la cuestión de inconstitucionalidad (SSTC 113, 114 y 115/2016) pese a la posición del magistrado Xiol Ríos, quien ha venido sosteniendo que la prevalencia permite a 
los jueces ordinarios resolver de modo natural estos conflictos, sin entrometerse en la función del Tribunal Constitucional (M. Ahumada Ruiz, 2016, 250).

Sin embargo, en sentencias posteriores se introducen matices que hacen menos excepcional esta aplicación de la regla de la prevalencia. Así, en la STC 204/2016 ya no se aplica sólo en los casos de normas autonómicas que reproduzcan normas básicas, sino también cuando la norma autonómica hubiera sido dictada en ausencia de norma básica. El criterio, por tanto, ya no es la deficiente técnica legislativa sino que se trata de «una ley autonómica a la que, en el momento en el que se dictó, no podía imputarse vicio alguno de inconstitucionalidad y que, sin embargo, deviene incompatible con una ley básica del Estado aprobada con posterioridad» (FJ 3). Además, tampoco parece exigirse que el Tribunal Constitucional se hubiese pronunciado previamente sobre el carácter básico de la regulación estatal. Los únicos elementos que parecían mantenerse es que se trataba de una inaplicación de la norma autonómica por parte de la administración como «operador jurídico primario» y ser supuestos de inconstitucionalidad mediata sobrevenida, esto es, modificación de bases estatales que provocan la inconstitucionalidad sobrevenida de normas autonómicas preexistentes. Finalmente, tras la STC 1/2017, en realidad, sólo resulta aplicable el segundo: la inconstitucionalidad mediata sobrevenida. Las referencias al operador jurídico primario han desaparecido y se trata de una aplicación de la regla de prevalencia por el órgano judicial ${ }^{12}$. Estamos, por tanto, ante una generalización incondicionada de la doctrina de la prevalencia en este supuesto de norma básica posterior que contradice norma autonómica anterior, sin que el órgano judicial albergue dudas sobre dicha contradicción. De esta forma, como indica el magistrado Martínez Vares en su voto particular a la STC 204/2016, se abre una vía de entrada en nuestro sistema de jurisdicción constitucional al modelo de control difuso de la inconstitucionalidad de las leyes (autonómicas) sin hacer los reajustes necesarios para evitar la inseguridad jurídica, por ausencia de uniformidad, y preservar la posición de los parlamentos autonómicos, en cuanto no pueden alegar ante el órgano judicial ordinario.

\section{CONCLUSIÓN. LA NECESIDAD DE MODIFICAR LA FORMA DE DETERMINAR LO BÁSICO}

Llegados a este punto, podemos sostener que resulta irreconocible en la práctica la concepción constitucional inicial de las competencias compartidas bases-desarrollo como una forma de reparto en la que las normas autonómicas complementaban a las estatales reflejando, en una misma fórmula, los principios de unidad y autonomía del artículo 2 CE. Por ello, planteamos una necesaria reconfiguración de esa relación que

${ }^{12}$ En el supuesto de la STC 1/2017 el Tribunal no cuestiona que el órgano judicial pueda aplicar la nueva doctrina sobre la prevalencia sino que en ese caso no se trata de una inconstitucionalidad sobrevenida de la norma autonómica y, por tanto, el órgano judicial debería haber planteado la cuestión de inconstitucionalidad. 
permita seguir utilizando esta categoría competencial sin que conlleve la supresión de las competencias autonómicas. Resultan habituales tanto en la doctrina académica como en el debate político las propuestas de eliminar este modo de reparto de competencias. Sin embargo, la opción no es realista. En un Estado compuesto, siempre habrán de preverse formas de compartición de competencias en las que el Estado establezca de una u otra forma un tratamiento común a partir del cual actúen los territorios. Debemos avanzar en la clarificación del reparto competencial y en la determinación de las responsabilidades respectivas, en la línea seguida por el federalismo alemán con la reforma de 2006. La experiencia de los sistemas federales ha mostrado que cuando varios actores comparten la regulación de una materia hay dificultades para asignar la responsabilidad respectiva y ello incide negativamente en el principio democrático en virtud del cual la ciudadanía debe saber quién es responsable de cada actuación para decidir en consecuencia. Sin embargo, hemos de convivir con las competencias compartidas. Incluso en Alemania, aunque la reforma de 2006 se sustentaba en la clarificación de las responsabilidades políticas a través de un reparto estricto y exhaustivo en cada uno de los ámbitos materiales entre la Federación y los Länder, finalmente, se mantuvo el reparto funcional de tareas, sin perjuicio de que la legislación concurrente haya quedado desdibujada en sus contornos (A. Arroyo Gil, 2009, 32, 53). Pero, especialmente en los federalismos de devolución, caracterizados por un proceso de descentralización paulatina, resultan necesarios los elementos comunes que, a su vez, pueden tener un desarrollo diferente en los diversos territorios. En este sentido, resultara necesaria una actuación del legislador común para garantizar unas condiciones equivalentes de vida en todo el territorio del Estado; condiciones básicas de igualdad en el ejercicio de derechos, especialmente de derechos sociales; la unidad económica para garantizar la unidad de mercado o evitar barreras en el tráfico económico o la unidad jurídica en todo el Estado ante una distorsionante diversidad. Además, aunque pretendamos que ese mínimo común se recoja en una ley y tenga un alcance limitado es inevitable que siquiera de forma excepcional esa ordenación de la materia, común para todo el territorio, se contenga en normas infralegales o vaya más allá de los principios. Y tampoco podemos pretender que el tratamiento común previamente establecido se mantenga inalterable en el tiempo pues deberá adaptarse a los cambios en la realidad social y a la aparición de nuevos fenómenos, aunque ello provoque la inconstitucionalidad sobrevenida de muchas normas plenamente vigentes y válidas en los distintos territorios ${ }^{13}$.

13 En cualquier caso, respecto a las bases, tenía razón García Morillo cuando consideraba que «puede hablarse de una cierta rigidez material de lo básico, al menos en lo que a la posible expansión de lo básico se refiere, porque el legislador que en un momento dado reguló una materia delimitó al hacerlo — siquiera fuera temporalmente- el campo de lo básico y simultáneamente excluyó de ese campo a todo lo no catalogado como tal, por lo que difícilmente podrá luego sostener con fundamento, salvo que las circunstancias hayan variado radicalmente que lo que antes no era básico si lo es ahora» $(1996,132)$. Es lo que Caamaño ha denominado el «principio de no reformulación sucesiva de la materia básica» (F. CAAMAÑo, 2000, p. 112). 
Desde esta perspectiva, descartada la opción de eliminar lo básico en el Estado autonómico debe replantearse la relación de esas bases estatales con el desarrollo normativo que corresponde a las Comunidades Autónomas en las competencias compartidas. Dicha reconfiguración debe asentarse sobre tres pilares. En primer lugar, su definición política, con participación de las propias Comunidades, cuyo derecho propio resulta afectado por la alteración de las bases; en segundo lugar, la recuperación de una estructura formal que las haga reconocibles en cuanto a la fuente en la que se incluyen y a su determinación expresa y, en tercer lugar, la acotación de su alcance o extensión a un mínimo común de forma que permita el desarrollo de políticas propias de las Comunidades.

El instrumento para hacer efectiva esa reconfiguración es la reforma constitucional. En el primer supuesto porque resulta imprescindible el reconocimiento constitucional de una nueva forma de determinar lo básico. En los otros dos (la fuente y el alcance o extensión) podría hacerse a través de un cambio en la doctrina del Tribunal Constitucional. Sin embargo en aras de superar la función que ha venido cumpliendo en la delimitación de competencias entre el Estado y las Comunidades Autónomas, resulta esencial recoger en la Constitución los elementos que sirven para definir lo básico, tanto en su forma como en sus límites.

1. En el primer sentido, resulta relevante sustituir el actual modelo de determinación y modificación de lo básico. Se sustenta, como hemos destacado, en la definición política unilateral por parte del legislador estatal o por el legislador autonómico cuando aquél no lo había hecho. En caso de conflicto, el Tribunal Constitucional se convierte en delimitador último de las competencias en esta relación bases-desarrollo. Frente a ello, sostenemos la necesidad de garantizar una determinación política de lo básico, pero no unilateral. Las Comunidades deben participar junto al Estado en la concreción de lo que es básico en cada uno de los ámbitos materiales compartidos. Defendemos, por tanto, una determinación política consensuada entre el Estado y las CCAA, que evite la recurrente intervención del Tribunal Constitucional en el reparto del poder político territorial.

Esa determinación política consensuada de lo básico requiere la intervención de un órgano constitucional en el que estén representados los territorios. En ese sentido, resulta precisa una reforma constitucional que convierta al actual Senado en un Consejo territorial entre cuyas funciones esté la de aprobar las normas básicas, que también deberán ser aprobadas en el Congreso como órgano constitucional que representa a la ciudadanía. Esa participación de las Comunidades en la decisión sobre lo que es básico en cada materia y en cada momento sólo será efectiva si se hace a través de los órganos de dirección política de los territorios, esto es, de sus gobiernos, presentes en el mencionado Senado convertido en Consejo territorial (E. Aja, 2014, 175; J.A. Montilla, 2016, 538; X. Arzoz, 2016, 230). En definitiva, lo básico establecido por los representantes de la soberanía popular deberá ser aceptado también por las Comunidades en el Consejo territorial. 
Las consecuencias benéficas de esta forma de determinar lo básico pueden advertirse en distintos ámbitos.

Por un lado, permite un desarrollo armónico de esas bases estatales en los ordenamientos autonómicos, sobre los que incide directamente. Resulta claro que las bases no pueden ser inamovibles ni pueden quedar petrificadas en el tiempo sino que deberán adaptarse a las nuevas realidades sociales y económicas. Incluso, aunque inicialmente parecía aceptarse la necesidad de una mayor estabilidad de las bases, se ha asentado el reconocimiento de la libertad de configuración del legislador estatal en el ejercicio de su competencia básica como una «legítima opción política» que no puede ser fiscalizada por el Tribunal Constitucional en cuanto no es juez de oportunidad (STC 48/2013/4), de lo que deriva la constante mutabilidad de las bases. Los efectos negativos para los ordenamientos autonómicos de esta concepción de las bases «como algo relativo y circunstancial a decidir por el legislador estatal en función de las coyunturas variables» (T. de la Quadra-Salcedo Janini, 2004, 143) parecen evidentes $^{14}$. Como hemos visto, la aprobación de una norma básica contraria a normas autonómicas vigentes provoca la inconstitucionalidad sobrevenida de éstas si el legislador básico estatal ha actuado en ejercicio de su competencia constitucional. Ante esta situación, se ha sostenido la necesidad de razonar y justificar las alteraciones de lo básico (J. García Morillo, 1996, 149-150) o incluso el principio de «no reformulación sucesiva de lo básico» (F. Caamaño, 2000, 112). Sin embargo, es necesario avanzar en esa garantía. Por ello, la previsión constitucional de la participación autonómica en la configuración de lo básico a través de un Consejo territorial formado por los órganos de dirección política de las Comunidades permite a éstas no sólo participar en la decisión sino también conocer las normas autonómicas que deberán ser modificadas por ser contrarias a lo básico como una garantía de certidumbre jurídica ${ }^{15}$.

En este mismo sentido, para evitar los problemas derivados de esta situación resulta razonable prever que la nueva norma básica entrará en vigor varios meses después de su publicación, de forma que las Comunidades tengan tiempo para adaptar su ordenamiento a la nueva regulación básica y se eviten colisiones normativas que afectan al principio de coherencia del ordenamiento.

Por otro lado, la definición política consensuada de lo básico permite también reducir la altísima conflictividad entre el Estado y las CCAA que ha convertido a nuestro modelo en un auténtico «federalismo de conflicto». Como hemos comprobado, en el modelo actual corresponde al Tribunal Constitucional decidir en cada caso lo que es básico y lo que no lo es a partir de la definición política inicial que efectúa

${ }^{14}$ Como indica X. Arzoz, «cuando menos cabría diferenciar entre los sectores regulatorios dotados de gran dinamismo y que requieren una constante adaptación de las bases, por un lado, y los sectores que no debieran estar sujetos a tanta variación (como la educación), por otro» (2016, 219).

15 En un sentido mucho más genérico al planteado en este texto el Tribunal se ha referido a las «garantías de certidumbre jurídica necesarias para asegurar que las Comunidades Autónomas puedan conocer cuál es el marco básico al que deben someter su competencia de desarrollo legislativo» (STC 48/2013/4). 
libremente el legislador estatal. Esto conlleva un riesgo para el Tribunal Constitucional en cuanto lo sitúa en el centro del debate sobre el reparto del poder territorial, que es un debate político. Pero, más allá del riesgo de deslegitimación, la presencia activa del Tribunal en la delimitación de lo básico implica que los actores políticos titulares de la competencia, Estado y Comunidades Autónomas, acuden al Tribunal cada vez que se produce una delimitación de lo básico, positiva por el legislador estatal o negativa por las CCAA, para que el Tribunal valore si han actuado en el marco de su espacio competencial. Ello explica que, más allá de la conflictividad desarrollada en la jurisdicción ordinaria, el número de conflictos competenciales que llegan al Tribunal Constitucional a través de las distintas vías procesales previstas en la Ley Orgánica (conflictos positivos y negativos de competencia, recurso de inconstitucionalidad y cuestión de inconstitucionalidad) sea en España muy elevado en comparación con otros Estados descentralizados como Alemania. Si corresponde al Tribunal Constitucional determinar lo que es básico, no puede resultar sorprendente que los distintos actores, en especial las CCAA, acudan a éste órgano constitucional para que lo determine sin aceptar la delimitación efectuada unilateralmente por el legislador estatal. Es una consecuencia inexorable de la concepción jurisdiccional de lo básico (E. Aja, 2014, 191) frente a la que planteamos su definición política con participación de las CCAA.

Esta determinación política consensuada de lo básico sólo resultará efectiva cuando culmine la reforma constitucional en el sentido indicado. No obstante, hasta ese momento pueden cumplir esa función de gobierno compartido, con un alcance distinto, las conferencias sectoriales ${ }^{16}$. Aun sin consecuencias jurídicas, las conferencias sectoriales deberían conocer y debatir las distintas normas básicas que pretenda aprobar el Estado a fin de que sus posibles efectos jurídicos sean conocidos con antelación por las CCAA.

2. En este marco de determinación política consensuada, resulta lógico que lo básico se establezca en una fuente con rango de ley y específicamente en una ley. Algunas de las razones habían sido expuestas por el propio Tribunal Constitucional hasta su cambio de doctrina en la STC 31/2010, a la que nos hemos referido antes. El principio de ley formal se nos presentaba como una garantía de seguridad y certidumbre jurídica, en cuanto permite saber cuáles son las bases. A ello pueden añadirse otras razones. Así, se ha aducido para justificar ese carácter, su capacidad para condicionar la validez de otras leyes (F. Caamaño, 2000, 107) o también podemos referirnos a la especial vinculación de la ley al principio democrático pluralista en cuanto hace posible el debate político-publico sobre el contenido de lo básico. Eso no implica negar la posibilidad de incluir las normas básicas en una fuente infralegal

${ }^{16}$ En el Informe sobre la Reforma del Estatuto elaborado en 2003 por la Generalitat de Cataluña como paso previo a la reforma de su Estatuto se planteaba la fijación de las bases en la Comisión bilateral Estado-Generalidad. Sin embargo, el carácter de mínimo común en todo el territorio encaja mal con esa definición bilateral, salvo en supuestos excepcionales. 
pero con un carácter estrictamente excepcional: cuando lo prevea la propia ley o cuando exista una conexión material, no puramente formal, de carácter teleológico. En cualquier caso, la fuente infralegal de carácter básico también debería ser sometida al Consejo territorial para garantizar la participación de las Comunidades también en ese supuesto. En este sentido, la Constitución podría recoger las exigencias formales que se han incluido en los Estatutos de Autonomía de segunda generación al pretender la definición estatutaria de lo básico y el Tribunal ha impedido en la STC 31/2010, como ya hemos explicado. Tras la doctrina de esta sentencia según la cual la inclusión de las bases en normas infralegales no es una excepción sino «elementos de la definición del contenido y alcance de la competencia atribuida al Estado» resulta necesario constitucionalizar la referencia a la fuente en la que debe incluirse lo básico (J.A. Montilla, 2015, 105).

3. En tercer lugar, deberían exigirse algunas condiciones al alcance de lo básico en la configuración que realice el legislador estatal, de manera que se garantice a las Comunidades el despliegue de su competencia de desarrollo normativo, más allá de la forma que revistan esas bases. El elemento limitador debería ser el que establecen los Estatutos de Autonomía de segunda generación y no ha sido cuestionado por el Tribunal Constitucional en la STC 31/2010. En el ejercicio de su título competencial de desarrollo normativo, las CCAA deben poder desarrollar políticas propias. En puridad, las Comunidades no desarrollan las bases sino, como hemos apuntado antes, legislan en el espacio competencial que le es propio en virtud de una potestad normativa originaria atribuida por la Constitución y los Estatutos. Desde esa perspectiva, es necesario que la legislación básica estatal le permita el despliegue de políticas propias. Ese es el sentido constitucional de la articulación bases-desarrollo que ha sido desvirtuado en la reciente doctrina del Tribunal Constitucional y debería recuperarse. Podría hacerse a través de la propia jurisprudencia constitucional, retornando y actualizando la doctrina originaria del Tribunal ${ }^{17}$. Sin embargo, la garantía efectiva sería la reforma constitucional en la que se reconocieran los principios que deben regir esta articulación normativa bases desarrollo.

17 Recuérdese la dicción literal de la STC 1/1982/1: «Lo que la Constitución persigue al conferir a los órganos generales del Estado la competencia exclusiva para establecer las bases de la ordenación de una determinada materia (...) es que tales bases tengan una regulación normativa uniforme y de vigencia en toda la Nación, con lo cual se asegura, en aras de intereses generales superiores a los de cada Comunidad Autónoma, un común denominador normativo, a partir del cual cada Comunidad, en defensa del propio interés general, podrá establecer las peculiaridades que le convengan dentro del marco de competencias que la Constitución y su Estatuto le hayan atribuido sobre aquella misma materia». Esa doctrina según la cual las bases estatales debían permitir el desarrollo de políticas propias en la materia se mantuvo en los años sucesivos. Por citar otra sentencia relevante, la STC 147/1991/4 señalaba que «la definición de las bases, en el ámbito de la legislación compartida, tiene por objeto crear un marco normativo unitario, de aplicación a todo el territorio nacional, dentro del cual las CCAA dispongan de un margen de actuación que les permita, mediante la competencia de desarrollo legislativo, establecer los ordenamientos complementarios que satisfagan sus peculiares intereses». 
En este sentido, el desarrollo normativo autonómico en ejercicio de su título competencial compartido debería regirse por el principio de no contradicción con las bases estatales. De esta forma, siempre que se respeten, esto es, que no se contradigan las condiciones básicas establecidas por el Estado, las Comunidades podrán legislar libremente (STC 32/1981/5). De esta forma, las bases estatales deberían configurar un mínimo, en cuyo contenido resulta implícita una determinada orientación política, como ha ocurrido en la práctica en la legislación medioambiental, a partir del cual resultan posibles opciones políticas mejorables por el legislador autonómico (J. García Morillo, 1996, 142-146; F. Caamaño, 2000, 109-110; X. Arzoz, 2016, 228). Ese mínimo no son necesariamente principios, puede ser una regulación sustantiva e incluso detallada cuando el supuesto lo requiera. Ese no es el elemento determinante. Lo es, por el contrario, que ese mínimo común, aplicable en todo el Estado, no impida una actuación normativa autonómica con una orientación política propia. No puede ser contradictoria, pues en ese caso la regulación en que se plasma también lo sería, pero tampoco tiene que limitarse a aplicar la solución adoptada por el Estado sino que puede ser divergente con ésta, si esa es la orientación que quiere dársele en un determinado territorio. A diferencia de lo que resulta de la STC 93/2015, desde la configuración constitucional de la relación bases-desarrollo no se puede considerar que un desarrollo normativo autonómico vulnera las bases estatales cuando se aparta de la respuesta dada por el legislador estatal ante un determinado supuesto de hecho sin entrar en contradicción con ella.

De esta forma, el principio que debe regir la relación bases-desarrollo no es el de «no vaciamiento» de las competencias autonómicas ni tampoco el de «no interferencia» en las políticas públicas del Estado sino el de «no contradicción» con las bases estatales. Ello garantiza el derecho a divergir, con la posibilidad de soluciones distintas a partir de las bases estatales en ejercicio del derecho a la autonomía ${ }^{18}$. La ventaja de este principio es que cuando, por las circunstancias concretas del supuesto, las bases estatales deban ser detalladas, como ocurre, por ejemplo, en materia económica, ello no impide el ejercicio de la competencia autonómica a través del desarrollo normativo pues puede seguir desplegando políticas propias siempre que no resulten incompatibles ${ }^{19}$. De esta forma, quedaría garantizado el sentido de lo básico como regula-

18 Aunque es una figura distinta a la que nos ocupa, procede apuntar que en el federalismo alemán se ha incluido tras la reforma de 2006 un nuevo tipo legislativo cual es la legislación divergente de los Länder. En virtud de ella, en determinados ámbitos materiales, que hasta ese momento eran objeto de la legislación marco y ahora aparecen como legislación concurrente, una vez que la Federación haya hecho uso de su competencia legislativa, los Länder pueden establecer por medio de ley una regulación distinta. Cfr. sobre ésta, A. Arroyo Gil, 2009, 59-70; M.A. Cabellos, 2012.

19 Como explicaba F. CAAMAÑo, la caracterización de la legislación básica como «barrera negativa o frontera de mínimos que permite a las CCAA legislar de modo diverso sobre lo básico, entendido ahora como materia, ampliando unidireccionalmente sus competencias legislativas, ofrece - frente a las tesis principialistas a las que indudablemente se aproxima - la ventaja de otorgar un fácil acomodo a los supuestos, excepcionales pero también inevitables, en los que ratione materia es imprescindible que facultades de ejecución formen parte de la competencia reservada al Estado» (F. CAAMAÑo, 2000, 112). 
ción normativa uniforme para asegurar intereses generales superiores a los de las CCAA, según cuales fueran estos, pero sin que ello suponga, como parece pretender el Tribunal Constitucional en su doctrina actual, determinar e incluso impedir el desarrollo normativo autonómico.

A nuestro juicio, sólo con estas condiciones, a partir de una definición política consensuada con las CCAA, establecida en ley parlamentaria y con un desarrollo normativo autonómico regido por el principio de no contradicción, de forma que permita el despliegue de políticas propias a las CCAA en esas materias, pueden mantenerse las bases como una técnica (necesaria) de legislación compartida y no como un instrumento de recentralización político-territorial.

\section{BIBLIOGRAFÍA CITADA}

AJA, E. (2014), Estado autonómico y reforma federal, Alianza, Madrid.

Albertí Rovira, E. (1986), «Leyes medida y distribución de competencias: un paso más en la interpretación extensiva de las bases normativas en la jurisprudencia constitucional», Revista Española de Derecho Constitucional, 18.

Alvarez Conde, E. (2004), «La legislación básica como parámetro de validez de la normativa autonómica», Revista Española de la Función Consultiva, 2.

Arroyo GIL, A. (2009), La reforma constitucional del federalismo alemán, IEA, Barcelona.

Arzoz Santisteban, X. (2016), «¿Reforma o abandono de la legislación básica como técnica de delimitación de competencias?», Revista d'Estudis Autonòmics i Federals, 23.

Balaguer Callejón, F. (1992), Fuentes del Derecho. II. Ordenamiento general del Estado y ordenamientos autonómicos, Tecnos, Madrid.

- (2005), «Las cuestiones competenciales en los actuales procesos de reforma de los Estatutos de Autonomía», Revista General de Derecho Constitucional, 1.

CaAmaño, F. (2000), «El abandono de lo básico: Estado autonómico y mitos fundacionales», Anuario de Derecho Constitucional y Parlamentario, 12-13.

Cabellos EspiÉrRez, M.A. (2012), «Nuevas formas de distribución competencial: la legislación divergente en el federalismo alemán», Revista Española de Derecho Constitucional, 96.

De la Quadra Salcedo Janini, T. (2004), «¿Es el Estatuto de autonomía una norma capaz de modular la legislación básica del Estado?, Revista Española de Derecho Constitucional, 72.

- (2005), «La reforma de los Estatutos de Autonomía y sus límites constitucionales. La imposibilidad de blindar las competencias autonómicas a través de una mera reforma estatutaria», Cuadernos de Derecho Público, 24.

Garcia De Enterria, E. (1985), Estudios sobre autonomías territoriales, Civitas, Madrid. 
Garcia Morillo, J. (1996), «La versatilidad de lo básico», Revista de Administración Pública, 139.

Jiménez CAMPo, J. (1989), ¿Qué es lo básico? Legislación compartida en el Estado autonómico, Revista Española de Derecho Constitucional, 27.

Montilla Martos, J.A. (2003), «Los elementos formales en el proceso de producción normativa de lo básico», Revista Española de Derecho Constitucional, Revista Española de Derecho Constitucional, 68.

- (2006), «La legislación básica tras las reformas estatutarias», Revista Española de Derecho Constitucional, 78.

- (2013), «The function of the Constitutional Court in the Distribution of Competences: A critical vision», en A. López BASAguren; L. EsCAjEdo (editors), The Ways of Federalism in Western Countries and the Horizons of Territorial Autonomy in Spain, Springer Verlag, Berlin-Heidelberg.

- (2015), Reforma federal y Estatutos de segunda generación, Thomsom-Reuters, Navarra.

- (2016), «Las competencias compartidas en España. Una propuesta de reconfiguración de las bases del Estado», Italian Papers on Federalism, 3.

Muñoz Machado, S. (1981), Las potestades legislativas de las Comunidades Autónomas, Civitas, Madrid.

Pemán Gavín, J.M. (2008), «Las competencia del Estado sobre la moneda y el sistema financiero», en M.E. Casas BAAmonde, M. Rodríguez-Piñero Y Bravo Ferrer, Comentarios a la Constitución española, Fundación Wolters Kluwer, Madrid.

Requejo Pages, J.L., Duque Villanueva, J.C., Ortega Carballo, C., AhumaDA RuIz, M. (2016), «Doctrina del Tribunal Constitucional durante el segundo cuatrimestre de 2016», REDC, 108.

Title:

The evolution of the shared competence bases-development

\section{Summary:}

1. The shared competences bases-development in the Constitution; 2. The material conception of the basics as a guarantee of autonomous regulatory development in the origins of the Autonomous State; 3. The formalization of the basics and its limits; 4. The deformalisation and unlimited expansion of the basics from STC 31/2010; 5 . The imposition of the bases 
on the Statute of autonomy from STC 31/2010; 6. The application of the clause of prevalence for the non-application of autonomous rules contrary to databases which have arisen; 7. Conclusion: the need to modify the way to determine the bases.

\title{
Resumen:
}

En este trabajo se analiza la evolución de las competencias compartidas en España, cuando al Estado corresponde establecer las bases en una materia y a las Comunidades Autónomas el desarrollo normativo y la ejecución. La concepción material de las bases fue concebida como una garantía para el ejercicio de las competencias autonómicas en el supuesto de inactividad del Estado. Por ello, tenía un carácter temporal. Sin embargo, se ha convertido en la práctica en un cauce que permite al Estado agotar la regulación de la materia. Esta situación ha resultado consolidada tras la sentencia del Tribunal Constitucional sobre el Estatuto de Autonomía de Cataluña en cuanto se han eliminado los límites que hasta ese momento había puesto al legislador estatal para determinar las bases en una materia de competencia compartida. En este contexto, se propone una reconfiguración de la forma de determinar las bases del Estado, con participación de las Comunidades Autónomas.

\begin{abstract}
:
In this paper, the evolution of shared competence in Spain is analyzed, when the State has to establish the bases in a subject and the Autonomous Communities the normative development and execution. The material conception of the bases was conceived as a guarantee for the exercise of autonomic competence in the case of state inactivity. Therefore, it had a temporary character. However, in practice it has become a channel that allows the State to exhaust the regulation of matter. This situation has been consolidated after the judgement of the Constitutional Court on the Statute of Autonomy of Catalonia as soon as the limits that until that moment had put to the state legislator to determine the bases in a matter of shared competence have been eliminated. In this context, a reconfiguration of the way to determine the bases of the State is proposed, with the participation of the Autonomous Communities.
\end{abstract}

\section{Palabras clave:}

Competencias compartidas, bases, desarrollo normativo, Estatuto de Autonomía, Tribunal Constitucional.

\section{Key words:}

Shared competence, bases, normative development, Statute of Autonomy, Constitutional Court. 